\title{
A survey of Zambian views on Chinese People and their involvement in Zambia
}

\section{By Gérard van Bracht*}

"We feed them, provide them with income, and still they are not happy... We provide loans, we donate... We helped many countries, but even these countries are complaining about the Chinese government ... We help, we pay, they have no gratitude... Not just Zambia, the world is complaining about China, and China is complaining about the world. I don't know why."1

-Senior spokesperson of large state-owned Chinese construction company, Lusaka

Only a few years ago, in 2006, Chinese shop owners in Lusaka were attacked during post-election riots, "as a presidential election sparked a backlash against Beijing's growing influence in Africa" (The Telegraph; 2006). The following year, Hu Jintao cancelled a visit to the economic Zone in Chambishi, a mining town in Zambia's Copperbelt Province, due to local anger over an accident that killed dozens of Zambian workers two years earlier. The image that has arisen as a result of these and subsequent events, is one of widespread anti-Chinese resentment among Zambians. At the same time, China has risen to become one of

* The author completed a Masters thesis on Chinese immigrants in Zambia as part of his master's degree in Chinese politics at Renmin University of China in Beijing. 


\section{AFRICAN \\ EAST-ASIAN \\ AFFAIRS \\ THE CHINA MONITOR}

Zambia's top trading partners, with investments across the board, and a plurality of its actors visibly on the ground in Zambia (Bank of Zambia; 2011). With this discrepancy in mind, this paper explores the twin questions of how ingrained anti-Chinese sentiment in Zambia is, and how to account for the idea that Zambian people "resent" Chinese people in their own country.

\section{The "problem" of China in Zambia}

Over the last years, Zambia - one of the oldest diplomatic partners of China in Africa - has received notable attention for the reported anti-Chinese sentiment among the Zambian population. This is partly due to the rise of Michael Sata, founder of the Patriotic Front (PF), who after three previous unsuccessful attempts, won the September 2011 presidential election, unseating the Movement for Multi-Party Democracy (MMD) government. During his campaigns, Mr. Sata often vented his discontent with the activities of Lebanese, Indian, and, especially, Chinese migrants in Zambia, to the point of threatening to expel them (Patel 2006). "Zambia has... found it difficult to attract genuine investors and has become the prey of the rogue Chinese investors that have no regard for the welfare of those that are unfortunate enough to work for them, let alone the countries that have allowed them to exploit their natural resources and people." (Sata 2007: 3). On another occasion, Mr. Sata criticized Chinese investors for ill-treating "our people and that is unacceptable. We are not going to condone exploitative investors. This country belongs to Zambians." (Michael Sata quoted in Lee 2009: 664). Underscoring his discontent with Chinese misconduct in Zambia, in 2006 Sata promised to recognize Taiwan if he

55 (c) Centre for Chinese Studies, Stellenbosch University

All Rights Reserved. 
Gérard van Bracht

A survey of Zambian views on Chinese People and their involvement in Zambia

were elected, antagonizing the Chinese ambassador to Zambia (Brautigam 2009).

Foreign attention toward Zambia and Sata's rhetoric related to a number of high-profile events involving Chinese people in Zambia. In April 2005, 52 Zambians were killed in an explosion at the subsidiary of NonFerrous China Africa (NFCA), the BGRIMM explosives factory (Fraser \& Lungu 2006). In February 2010, a Zambian miner killed a Chinese manager at the Collum Coal Mine in Sinazongwe. Thirteen Zambian miners were injured at the same mine in October 2010 when two Chinese managers, facing angry miners complaining about wages, shot into the crowd with a shotgun (The New York Times; 8 November 2010). And in the fall of 2011, four Chinese men were arrested for allegedly having had sexual intercourse with underage Zambian girls in Luanshya (IPS; 2012). These events have not gone unnoticed by the Western media. The New York Times (4 April 2011a) writes that the Collum Coal Mine shooting incident in 2010 "was viewed as an outrage by many Zambians who resent the enormous economic influence China has over their country." And according to Le Monde (23 September 2011), Michael Sata "plays on anti-Chinese sentiment" among the Zambian population. According to media reports, this anti-Chinese sentiment has other causes as well. The $B B C$ (5 February 2011) interviewed a Zambian woman who sells chickens, saying that the Chinese "are going to drive us out of business... If they want to have small, small businesses ... let them go back to China and do those small, small businesses in China, not here." The Economist (20 April 2011) reports that "the recent arrival of Chinese traders in the grimy alleys of Soweto market in Lusaka [has] halved the cost of chicken. Cabbage prices dropped by $65 \%$... 'How dare 


\section{AFRICAN \\ EAST-ASIAN \\ AFFAIRS \\ THE CHINA MONITOR}

the Chinese disturb our market,' says Justin Muchindu, a seller." Granting the fact that the image of Chinese actors and their activities in Africa and Zambia that thus emerges from these (arbitrarily chosen) excerpts merely the most negative one of several paradigms of the "Chinain-Africa" debate (Chatelard; 2011), these quotes make one thing clear: there is large-scale discontent with the Chinese, perhaps even antiChinese prejudice, in Zambia.

However, reality is more complicated than the picture presented above makes one believe. This is reflected in recent scholarly contributions in the field of China-Africa which have debunked many of the "myths" that surround China's presence in Africa. For example, one particular myth that has been invalidated is the perception that the Chinese government sends workers to Africa under a plan to have them remain behind as traders (Huynh et al. 2010). Furthermore, sometimes the picture presented by media reports contains inaccurate information. For instance, The Economist (20 April 2011) writes that "the Chinese-built road from Lusaka, Zambia's capital, to Chirundu, 130km (81 miles) to the south-east, was quickly swept away by rains." In reality, a small part of the Lusaka-Chirundu road did wash away, about a hundred meters, which was not the fault of the Chinese company who constructed the $\operatorname{road}^{2}$. These nuances raise the question as to what extent the image of Zambian's perceptions of Chinese people in their country, as presented in the media and in some academic publications, reflects the views of the wider population and the situation on the ground. This also begs the question: if the above quoted media reports are right, what are the causes for this anti-Chinese sentiment in Zambia.

57 (c) Centre for Chinese Studies, Stellenbosch University All Rights Reserved. 
Gérard van Bracht A survey of Zambian views on Chinese People and their involvement in Zambia

Over the last few years of China-Africa migration, scholars have devoted much attention to the perception of Chinese activities and Chinese actors in the eyes of locals. Dobler (2009) reports that cheap Chinese goods as well as other factors have caused increased levels of anti-Chinese resentment against Chinese people in Namibia. Sautman and Yan's (2009) nine-country survey (including Zambia) on African's perceptions of Chinese people concludes that the African's views of Chinese people are "variegated and complex" (p. 729); their views often contain both positive and negative elements. Gadzala and Hanusch (2010), based on a Afrobarometer survey in twenty African countries, find that Africans have a generally positive view of Chinese people, but that there is genuine concern about China's impact on African societies in terms of human rights and the impact of Chinese imports on African economies. The authors conclude that "Africans on the whole approach China's African engagement in a deliberate and nuanced fashion" (Gadzala \& Hanusch 2010: 18). To this author's knowledge, however, a comprehensive qualitative research of Zambian people's perceptions of Chinese people in Zambia has not yet been conducted.

\section{Zambians views of Chinese people in Zambia}

This section, drawing on primary data collected during a three-month field study in Zambia (from December 2011 to February 2012), provides an evaluation of the role of Chinese people in Zambia based on structured interviews with 155 Zambian nationals (61 employees of a private Zambian company, 42 entrepreneurs or business owners, 21 employees of a Chinese company, 17 government officials, and 14 students or unemployed). The interviews were conducted orally with a 


\section{AFRICAN \\ EAST-ASIAN \\ AFFAIRS \\ THE CHINA MONITOR}

standard questionnaire, most in English but some were conducted in the local languages, Bemba and Nyanja, with the help of a Zambian interpreter. Additional in-depth interviews with Zambian and Chinese parties shed light on the nature of the Zambian perceptions as expressed in the questionnaire surveys.

The sample size was non-random, and, since the survey was conducted in four localities in Zambia (Livingstone, Lusaka, Chambishi and Mufulira; the latter two are mining towns), the conclusions are not representative of the views of the entire Zambian population. But the questionnaire survey does give an in-depth and qualitative picture of Zambian views of Chinese people. Second, although, as Ma Mung (2008) points out, "Chinese migrants" in Africa are not a homogeneous group, for practical reasons no differentiation was made in this research between different kinds of Chinese migrants or how they might be perceived by Zambians differently. Instead they are referred to as "Chinese people".

Based on psychological literature on causes of prejudice formation, a distinction is made between the impact of the Chinese presence upon the Zambian people and country on one hand, and the impact on the individual interviewee on the other. Blumer (1958) and Quillian (1995) argue that prejudice emerges if threats directed against the ingroup (in our case, the Zambian nation to which an individual Zambian belongs) affect this group's relative social position to other groups. Other authors contend that prejudice formation fundamentally is the product of conflicts of interest at the individual level (Bonacich; 1972, 1973, Kinder and Sears; 1981, Bobo and Hutchings; 1996, Sears et al.; 1979). For

59 (C) Centre for Chinese Studies, Stellenbosch University

All Rights Reserved. 
Gérard van Bracht A survey of Zambian views on Chinese People and their involvement in Zambia

instance, Bonacich (1973) argues that, because ethnic migrants usually are thrifty, economically successful, and do not integrate in the host society, they are prone to attract the jealousy and opprobrium of local people, who perceive their success as achieved in an unfair way and at the expense of the locals. This dual layer of analysis is applied here to assess the relative importance of the impact of Chinese activities in Zambia on Zambia and on the Zambian respondents.

The Zambian respondents answered the two following open-ended questions: "What positive impact does the presence of Chinese people in Zambia have on Zambia?" and "What negative impact does the presence of Chinese people in Zambia have on Zambia?". The questions were repeated ad nauseam, until the respondent indicated having nothing to add. This method was chosen over a closed-ended list with issues, to prevent "priming" of the interviewees answers. Table 1 lists the complaints and praise relating to Zambia. All the answers to these two questions were organized and put into categories to enable comparisons.

\section{Table 1: Impact on the Zambian nation $(\mathrm{N}=155)$}

\begin{tabular}{|c|c|l|c|}
\hline Positive & Total & Negative & Total \\
\hline I. Employment & $(78)$ & I. Treatment of workers & $(213)$ \\
\hline Job creation for Zambians & 74 & $\begin{array}{c}\text { Bad treatment of Zambian workers } \\
\text { (e.g. poor safety standards, low wag- } \\
\text { es, violating Zambian labor law, } \\
\text { casualization) }\end{array}$ & 157 \\
\hline $\begin{array}{c}\text { Chinese employers offer good } \\
\text { work conditions/ transfer of } \\
\text { skills/training }\end{array}$ & 4 & $\begin{array}{c}\text { Verbally or physically abusing Zam- } \\
\text { bian workers; killing Zambian work- } \\
\text { ers (e.g. BGRIMM explosion) }\end{array}$ & 44 \\
\hline
\end{tabular}




\section{AFRICAN \\ EAST-ASIAN \\ AFFAIRS}

\begin{tabular}{|c|c|c|c|}
\hline & & $\begin{array}{c}\text { Importing Chinese laborers who take } \\
\text { jobs that Zambians can do }\end{array}$ & 12 \\
\hline II. Economy and development & $(250)$ & II. Economy and development & $(73)$ \\
\hline $\begin{array}{l}\text { Chinese investments are good } \\
\text { for Zambia (e.g. shops, manu- } \\
\text { facturing, tourism, mining) }\end{array}$ & 113 & $\begin{array}{c}\text { Bringing in too many or low-skilled } \\
\text { Chinese workers; importing Chinese } \\
\text { criminals to work in Zambia }\end{array}$ & 5 \\
\hline $\begin{array}{c}\text { Construction of Tanzam Rail- } \\
\text { way }\end{array}$ & 19 & $\begin{array}{l}\text { Making or selling low-quality/fake } \\
\text { goods (incl. electronics, poultry, } \\
\text { roads) }\end{array}$ & 34 \\
\hline $\begin{array}{c}\text { (Financial) assistance (e.g. soft } \\
\text { loans); social projects } \\
\text { (orphanages etc.); China being a } \\
\text { good partner (e.g. no strings at- } \\
\text { tached help); increase the level of } \\
\text { medical care in Zambia (e.g. Chi- } \\
\text { nese clinics) } \\
\end{array}$ & 60 & $\begin{array}{l}\text { China does not do enough to help } \\
\text { Zambia; Chinese people do things } \\
\text { that hurt Zambia (e.g. stealing cop- } \\
\text { per, causing pollution) }\end{array}$ & 29 \\
\hline $\begin{array}{c}\text { Chinese consumer products have } \\
\text { a positive impact on Zambia } \\
\text { (clothes, machines, cars, technol- } \\
\text { ogy, lower costs of living) }\end{array}$ & 58 & Other & 5 \\
\hline III. Business & (5) & III. Business & $(23)$ \\
\hline $\begin{array}{c}\text { Chinese people buy Zambian } \\
\text { goods, give Zambian people busi- } \\
\text { ness }\end{array}$ & 1 & $\begin{array}{c}\text { Unfair competition by Chinese com- } \\
\text { panies; crowding out of Zambian } \\
\text { businesses; saturating the Zambian } \\
\text { market }\end{array}$ & 12 \\
\hline \begin{tabular}{|c|} 
Zambian people employed by \\
Chinese companies have higher \\
purchasing power, has a positive \\
effect on business in Zambia
\end{tabular} & 1 & $\begin{array}{l}\text { Chinese people do business that } \\
\text { Zambian people can do }\end{array}$ & 11 \\
\hline $\begin{array}{c}\text { Chinese people increase the com- } \\
\text { petitiveness of Zambian compa- } \\
\text { nies }\end{array}$ & 3 & & \\
\hline
\end{tabular}


Gérard van Bracht

A survey of Zambian views on Chinese People and their involvement in Zambia

\begin{tabular}{|c|c|c|c|}
\hline IV. Social behavior & $(32)$ & IV. Social behavior & $(96)$ \\
\hline \multirow[t]{2}{*}{$\begin{array}{c}\text { Positive impact of Chinese cul- } \\
\text { ture/thinking/work ethic; Chinese } \\
\text { people and Zambians get along; } \\
\text { Chinese people are not racist } \\
\end{array}$} & 32 & $\begin{array}{l}\text { Non-sexual related amoral behavior } \\
\text { (conducting abortions, anti-Zambian } \\
\text { racism, encouraging corruption, } \\
\text { rudeness, bad character, spitting etc.) }\end{array}$ & 27 \\
\hline & & $\begin{array}{c}\text { Sexual related amoral behavior (e.g. } \\
\text { encouraging prostitution, raping } \\
\text { Zambian girls in Luanshya, impreg- } \\
\text { nating and abandoning Zambian } \\
\text { girls) } \\
\end{array}$ & 69 \\
\hline V. Infrastructure & (148) & V. Language and culture & (17) \\
\hline $\begin{array}{l}\text { General infrastructure develop- } \\
\text { ment (including houses, schools, } \\
\text { bridges, roads, etc.) }\end{array}$ & 66 & $\begin{array}{l}\text { Chinese work culture is different } \\
\text { from Zambian work culture }\end{array}$ & 1 \\
\hline $\begin{array}{l}\text { Roads and/or bridges (specifically } \\
\text { mentioned) }\end{array}$ & 59 & $\begin{array}{l}\text { Chinese people do not integrate into } \\
\text { Zambian society; do not understand } \\
\text { Zambian language and culture, do } \\
\text { not understand how Zambian people } \\
\text { live, are not friendly to Zambian }\end{array}$ & 16 \\
\hline $\begin{array}{c}\text { Stadiums (specifically men- } \\
\text { tioned) }\end{array}$ & 23 & & \\
\hline Total positive & 513 & Total negative & 422 \\
\hline Respondents with no answer & 4 & Respondents with no answer & 10 \\
\hline
\end{tabular}

Almost half (48.7\%) of the positive statements focus on the contribution of Chinese people to the development of Zambia and the Zambian economy. Among them, the general contribution of Chinese people and companies was frequently mentioned (76 times). Chinese investments in the mines, mentioned 37 times, were especially important in the 


\section{AFRICAN \\ EAST-ASIAN \\ AFFAIRS \\ THE CHINA MONITOR}

Issue 1

August 2012

Copperbelt. In this respect, one Zambian mechanical engineer working for a large Chinese mining firm points out: "I have seen Chambishi transform from a mere small township into a larger industrial town. They built the smelter here, revived the mines. Luanshya [another mining town in Zambia's Copperbelt Province] was almost a ghost town at some point but now it's back to life." 3 The second category that stands out is China's investment in infrastructure in Zambia, which was mentioned 148 times by the interviewees ( $28.8 \%$ of all positive comments), a sign that that China's infrastructure investments are appreciated by Zambians. 19 people specifically mentioned the Tanzania-Zambia Railway, which was constructed by China between 1965 and 1975.

Fifty-eight positive comments related to the low price or availability of Chinese goods. China is often credited with increasing the purchasing power and living standards of people in Africa by bringing in inexpensive goods to Africa, which are much more affordable than both Western imports and many local products (Sautman \& Yan 2007), and this also applies to Zambia. Chinese people are also criticized for selling low-quality goods in Africa (Taylor 2009). The issue of inferior quality of Chinese products was mentioned by 34 respondents. Although many respondents are satisfied with the low price of Chinese products they buy in Chinese stores, many of them in the same breath criticize these products for their inferior quality. This is exactly what Haugen and Carling (2005) found for Cape Verde.

The treatment of workers, however, is clearly a major issue on the Zambian level for the respondents. Half of the total complaints $(50.5 \%)$ relate to the issue of treatment of Zambian workers, which are mostly about the low pay of workers and the verbal or physical abuse of workers. Twenty-

63 (c) Centre for Chinese Studies, Stellenbosch University

All Rights Reserved. 
Gérard van Bracht

five people specifically mentioned the Collum Coal Mine shooting or the BGRIMM-explosion in Chambishi. Chinese traders are often accused of crowding out local business in African countries, but as Marfaing and Thiel (2011) show for Ghana and Senegal, this charge is not always justified. In this survey, 23 complaints related to this issue, so a negative impact of Chinese entrepreneurs on Zambian business does seem to be a concern for some of the respondents. Another major area of complaint is the moral behavior of Chinese people in Zambia; $22.7 \%$ of the complaints related to this category. These complaints can be divided into two categories: non-sexual moral conduct and sexual moral conduct. The first category includes habits that some Zambians disapprove of, like spitting. The second category relates to "sexual issues", e.g. the complaint that Chinese men encourage prostitution. Especially the alleged abuse of Zambian girls in Luanshya by four Chinese men in 2011 led to fierce reactions from the part of the Zambian interviewees. The men were acquitted from charges in March 2012 (Lusaka Times 2012).

\section{Praise and complaints for the individual}

The questionnaire also contained two questions relating to the impact of the Chinese presence on the individual: "What positive impact does the presence of Chinese people in Zambia have on you, your family and friends?" and "What negative impact does the presence of Chinese people in Zambia have on you, your family and friends?" Table 2 lists the results. 


\section{AFRICAN \\ EAST-ASIAN \\ AFFAIRS}

THE CHINA MONITOR

Issue 1

August 2012

Table 2: Impact on the individual Zambian respondent $(\mathrm{N}=155)$

\begin{tabular}{|c|c|c|c|}
\hline Positive & Total & Negative & Total \\
\hline I. Employment & (144) & I. Treatment of workers & $(107)$ \\
\hline $\begin{array}{c}\text { A Chinese company employs me } \\
\text { or has employed me }\end{array}$ & 18 & $\begin{array}{c}\text { Chinese employer treats me bad at } \\
\text { work* }\end{array}$ & 23 \\
\hline $\begin{array}{c}\text { I can support my family, Chinese } \\
\text { company teaches me skills, work } \\
\text { conditions are not bad }\end{array}$ & 26 & $\begin{array}{c}\text { Bad treatment at work of my family } \\
\text { and/or friends* }\end{array}$ & 55 \\
\hline $\begin{array}{l}\text { A Chinese company employs } \\
\text { respondent's family and/or friends }\end{array}$ & 80 & $\begin{array}{c}\text { Bad treatment at work of Zambian } \\
\text { people in general }\end{array}$ & 29 \\
\hline $\begin{array}{l}\text { Respondent's family/friends/ } \\
\text { acquaintances have an income, } \\
\text { increases my purchasing power }\end{array}$ & 12 & $\begin{array}{c}*=\text { incl. bad treatment in general, or } \\
\text { specific complaints, like violation of } \\
\text { labor laws, low salaries, poor safety } \\
\text { standards, no transfer of skills, physi- } \\
\text { cal/verbal abuse etc. }\end{array}$ & \\
\hline $\begin{array}{l}\text { Chinese companies employ Zam- } \\
\text { bians (excl. my family members/ } \\
\text { friends) }\end{array}$ & 5 & & \\
\hline $\begin{array}{c}\text { Spill over effect on Zambia be- } \\
\text { cause many Zambians have an } \\
\text { income due to being employed by } \\
\text { Chinese company (e.g. less prosti- } \\
\text { tution and crime) }\end{array}$ & 3 & & \\
\hline II. Economy and development & (94) & II. Economy and development & $(40)$ \\
\hline $\begin{array}{c}\text { Chinese investments help Zambia } \\
\text { develop, this has a positive effect } \\
\text { on me/family members/friends }\end{array}$ & 21 & $\begin{array}{l}\text { Chinese people are selfish; they ben- } \\
\text { efit more than Zambians; they don't } \\
\text { do enough for Zambia }\end{array}$ & 6 \\
\hline
\end{tabular}


Gérard van Bracht

A survey of Zambian views on Chinese People and their involvement in Zambia

\begin{tabular}{|c|c|c|c|}
\hline $\begin{array}{c}\text { Medical facilities from which I } \\
\text { benefit (Chinese doctors, medical } \\
\text { equipment, Chinese medicine, } \\
\text { Chinese built hospitals etc.) }\end{array}$ & 21 & $\begin{array}{c}\text { Chinese products/services are of poor } \\
\text { quality, sometimes even increase } \\
\text { Zambian's costs of living }\end{array}$ & 27 \\
\hline $\begin{array}{c}\text { Chinese products have a positive } \\
\text { impact on me/family members/ } \\
\text { friends }\end{array}$ & 46 & $\begin{array}{l}\text { Grabbed my family's land without } \\
\text { proper compensation }\end{array}$ & 2 \\
\hline $\begin{array}{l}\text { Sponsored my/my family mem- } \\
\text { ber's/my friend's education }\end{array}$ & 3 & $\begin{array}{l}\text { Chinese people don't respect/don't } \\
\text { care about Zambian people }\end{array}$ & 3 \\
\hline Other & 3 & $\begin{array}{c}\text { There are too many Chinese people } \\
\text { in Zambia; Chinese people control } \\
\text { Zambia }\end{array}$ & 2 \\
\hline III. Business & $(23)$ & III. Business & $(25)$ \\
\hline $\begin{array}{c}\mathrm{Me} / \mathrm{my} \text { friend/family members do } \\
\text { business with Chinese people }\end{array}$ & 10 & $\begin{array}{l}\text { Chinese people compete with me } \\
\text { and/or have negative impact on my } \\
\text { business }\end{array}$ & 13 \\
\hline $\begin{array}{l}\text { I sell Chinese made products, } \\
\text { enables me to make a profit }\end{array}$ & 6 & $\begin{array}{c}\text { Chinese people compete with my } \\
\text { family member's/friend's business } \\
\text { and/or have negative impact on their } \\
\text { business }\end{array}$ & 5 \\
\hline $\begin{array}{l}\text { Zambian people have an income } \\
\text { due to being employed by Chinese } \\
\text { company, increases their purchas- } \\
\text { ing power, is good for my business }\end{array}$ & 5 & $\begin{array}{l}\text { Chinese businesses have a negative } \\
\text { effect on the company I work for } \\
\text { (lower bonus, Chinese pirate the } \\
\text { products we sell) }\end{array}$ & 5 \\
\hline $\begin{array}{c}\text { Chinese people increase the com- } \\
\text { petitiveness of Zambian compa- } \\
\text { nies }\end{array}$ & 2 & $\begin{array}{c}\text { Chinese businesses have a negative } \\
\text { effect on Zambian business in gen- } \\
\text { eral }\end{array}$ & 2 \\
\hline IV. Social behavior & (34) & IV. Social behavior & $(27)$ \\
\hline \begin{tabular}{|c|} 
Positive effect on myself because \\
of interaction with Chinese people \\
(Chinese culture/thinking/work \\
ethic, friendship, material and \\
spiritual support)
\end{tabular} & 33 & $\begin{array}{c}\text { Non-sexual related amoral behavior } \\
\text { (conducting abortions, anti-Zambian } \\
\text { racism, encouraging corruption, } \\
\text { rudeness etc.) }\end{array}$ & 12 \\
\hline
\end{tabular}




\section{AFRICAN \\ EAST-ASIAN \\ AFFAIRS \\ THE CHINA MONITOR}

Issue 1

August 2012

\begin{tabular}{|c|c|c|c|}
\hline $\begin{array}{l}\text { It is good that Chinese men marry } \\
\text { with Zambian women. }\end{array}$ & 1 & $\begin{array}{l}\text { Sexual related amoral behavior (e.g. } \\
\text { encouraging prostitution, raping } \\
\text { Zambian girls, impregnating and } \\
\text { abandoning Zambian girls in general }\end{array}$ & 15 \\
\hline V. Infrastructure & (35) & V. Language and culture & (5) \\
\hline $\begin{array}{l}\text { General infrastructure develop- } \\
\text { ment (including houses, schools, } \\
\text { bridges, roads, etc.) }\end{array}$ & 13 & $\begin{array}{c}\text { Communication problems affect my } \\
\text { work at a Chinese company }\end{array}$ & 2 \\
\hline $\begin{array}{l}\text { Roads and/or bridges (specifically } \\
\text { mentioned) }\end{array}$ & 19 & $\begin{array}{l}\text { Chinese people don't integrate into } \\
\text { Zambian society and/or don't under- } \\
\text { stand Zambian culture and language }\end{array}$ & 3 \\
\hline Stadium (specifically mentioned) & 3 & & \\
\hline Total positive & 330 & Total negative & 204 \\
\hline Respondents with no answer & 21 & Respondents with no answer & 56 \\
\hline
\end{tabular}

Whereas in Table 1 the economy and development category tops the list of positive comments, at the individual level, employment creation by Chinese people is clearly the most important positive impact on individual Zambians. $43.6 \%$ of all instances of all positive comments relate to employment. Eighty Zambians are grateful to Chinese companies for employing their family members and/or friends. Forty-six Zambians mentioned that Chinese products have a positive impact on their life, reflecting the importance of Chinese consumer goods for Zambians. Frequent mentioning of the fact that China has contributed to the development of medical facilities in Zambia (Chinese doctors, Chinese built clinics or hospitals, Chinese medicine, etc.) and that Chinese investments in general are beneficial to respondents themselves, provide evidence that also on the individual level there is certain

67 (c) Centre for Chinese Studies, Stellenbosch University

All Rights Reserved. 
Gérard van Bracht

A survey of Zambian views on Chinese People and their involvement in Zambia

appreciation for the development that Chinese companies and Chinese people bring to Zambia.

As for negative comments, complaints concerning the work conditions provided by Chinese companies top the list for comments on the negative impact on the individual interviewee. More than half $(52.5 \%)$ of the complaints relate to poor pay, bad work conditions, safety, violations of the Zambian labor laws, and verbal and physical violence. As in other African countries, all major Zambian cities have one or multiple "Chinese shops", a store of varying size run by one or two Chinese people and stocked with cheap consumer goods ranging from pens to shoes to children's toys (Haugen and Carling; 2005). With respect to the impact of Chinese investments on Zambian businesses, the results of the survey paint a complicated picture. The 42 Zambian business owners that were interviewed were also asked a separate question on the questionnaire. One-third of them explicitly complained that Chinese business activities in their locality have a negative impact on their own business. Especially Zambian sellers of chickens and second-hand clothes reported being affected by Chinese competitors. However, not every Zambian shop-owner experiences competition from Chinese businesses. Most Zambian owners of clothes boutiques denied experiencing competition from Chinese shops, because they cater to a different group of consumers, namely those who can afford to buy better quality clothing than the low-price, low-quality clothes that most Chinese shops offer. 


\section{AFRICAN \\ EAST-ASIAN \\ AFFAIRS \\ THE CHINA MONITOR}

\section{Indirect effects}

Table 2 contains italicized items which can be called the indirect effect of the Chinese presence in Zambia. These items indicate that several interviewees - when asked about the positive or negative impact of the Chinese presence on himself or herself - would mention an effect that did not directly advantage or disadvantage this person, but had an impact in an indirect way.

In order to show the indirect effect for labor, the relevant complaints were combined and put into three categories: those pertaining to the interviewee, those concerning the interviewee's friends or family members, and those relating to Zambians in general. From this it is clear that many Zambians feel they are indirectly affected by the labor abuses that affect their family and friends, or Zambians in general. On the positive side, not only do many Zambians appreciate the employment that Chinese people bring to Zambia, they also specifically mention various indirect positive effects on themselves due to employment created by Chinese companies. For instance, several respondents mentioned the fact that they themselves benefit from increased employment created by Chinese companies. Zambian breadwinners can support their families because they have a job, the result of which is that their family and friends are financially less dependent on them because they earn their own income. As a local government official in Chambishi points out: "In Zambia we have that dependency syndrome, where you have to share your salary with family members and your friends, but now that they have jobs I don't have to share anymore."4 Twenty-six Zambians 
Gérard van Bracht

A survey of Zambian views on Chinese People and their involvement in Zambia

employed by a Chinese company report that they can support their family with their current job, learn new skills, or are generally satisfied with the work conditions; 12 Zambians mentioned that the fact that their family or friends have a job has increased their purchasing power; and 3 respondents reported a positive indirect effect on Zambia because of a general increase in employment due to Chinese companies.

Second, several Zambian business owners emphasized "spill over" effects of the Chinese presence in Zambia on their business. These effects include satisfaction with the Chinese products they sell because these products enable them to make a profit. The employment provided by Chinese companies in Zambia also increases the purchasing power of Zambian employees, who then spend more money in local shops. The owner of a grocery store in Chambishi explained that "most Zambian workers [here] work for the Chinese, [these Zambian workers] come spend money in my shop." "Indirect negative effects of Chinese competition on local business were also found: several Zambians who worked for Zambian firms complained that their bonus had decreased because the shop they worked in sold less due to Chinese competition, or that Chinese shops copied their goods and sold them for a lower price.

Third, the items under "social behavior" in Table 2 indicate that many Zambians feel that they are personally negatively affected by the general behavior of some Chinese people in Zambia. For instance, some respondents object to the fact that Chinese doctors conduct abortions in Zambia. On the positive side, 33 Zambians reported a favorable social impact of their interactions with Chinese people on their own life, because of the friendship or help they received from Chinese people. 


\section{AFRICAN \\ EAST-ASIAN \\ AFFAIRS \\ THE CHINA MONITOR}

It is important to be aware of these indirect positive and negative factors, because they may affect Zambian perceptions of Chinese people in a significant way. However, these indirect impacts are rarely mentioned in the literature on China-Africa. From these indirect effects one can also learn that many respondents are disinclined to make a distinction between what is "good/bad" for Zambia and what is "good/bad" the individual respondent (or for his friends and family members). As one Zambian journalist put it, certain Chinese abuses "do affect me. As a journalist you strive to improve the lives of people, report bad things, it brings you down emotionally." 6

\section{Anti-Chinese prejudice?}

The previous section provided an analysis of the benefits and drawbacks of the Chinese presence in Zambia in the eyes of the respondents. This section provides data on Zambian's perceptions of the nature of Chinese people from the viewpoint of attitudes. The questionnaire contained the question: "In your eyes, how many of the Chinese people in Zambia do you [...] ?", which was paired with eight attitude verbs listed in the left column in Table 3 . These verbs are partially derived from an attitude scale that has been used in psychology to measure prejudice (Stephan et al. 1998). To each of these verbs the respondent indicated on a seven-point Likert scale from 1 ("none of them") to 7 ("all of them") to what portion of Chinese people in his/her eyes the given attitude applies.

71 (c) Centre for Chinese Studies, Stellenbosch University All Rights Reserved. 
Gérard van Bracht A survey of Zambian views on Chinese People and their involvement in Zambia

Table 3: Distribution of attitudes towards Chinese people among 155 Zambian respondents (in \%)

\begin{tabular}{|c|c|c|c|c|c|c|c|c|c|}
\hline $\begin{array}{c}\text { Atti- } \\
\text { tude }\end{array}$ & None & $\begin{array}{c}\text { A } \\
\text { few }\end{array}$ & Some & Half & Most & $\begin{array}{c}\text { Almost } \\
\text { all }\end{array}$ & All & Missing & $\begin{array}{c}\text { Total } \\
(\%)\end{array}$ \\
\hline Like & 7.7 & 22.6 & 19.4 & 9 & 14.2 & 7.1 & 20 & 0 & 100 \\
\hline Dislike & 30.3 & 31.6 & 14.2 & 7.7 & 5.8 & 5.2 & 5.2 & 0 & 100 \\
\hline Trust & 19.4 & 33.5 & 23.9 & 7.7 & 5.8 & 3.2 & 6.5 & 0 & 100 \\
\hline Envy & 34.2 & 15.5 & 20 & 5.2 & 15.5 & 4.5 & 4.5 & 0.6 & 100 \\
\hline Fear & 60.7 & 7.7 & 16.7 & 1.3 & 6.5 & 1.3 & 4.5 & 1.3 & 100 \\
\hline Admire & 24.5 & 27.7 & 16.8 & 7.1 & 10.3 & 5.8 & 7.7 & 0 & 99.9 \\
\hline $\begin{array}{c}\text { Re- } \\
\text { spect }\end{array}$ & 2.6 & 10.3 & 12.3 & 5.8 & 21.3 & 7.7 & 40 & 0 & 100 \\
\hline Hate & 69 & 12.3 & 9 & 3.2 & 1.9 & 1.9 & 1.9 & 0.6 & 99.8 \\
\hline
\end{tabular}

Although there are no benchmarks to assess the absolute level of prejudice or the relative level compared with Zambian attitudes toward other foreigners, the results do tells us a few things. Although two-thirds of the 155 respondents expected to dislike "none" or "a few" Chinese people in Zambia, almost fifty percent expected to like less than half of the Chinese people in Zambia. This implies that even though there is no real dislike for Chinese people among the respondents, it cannot be argued that there is general fondness of them either. Interestingly, though, onefifth of the respondents indicated to like "all" Chinese people. Second, trust in Chinese people is generally low. Third, most of the respondents don't fear Chinese people at all. Forty percent of the respondents said to 


\section{AFRICAN \\ EAST-ASIAN \\ AFFAIRS \\ THE CHINA MONITOR}

respect all Chinese people in Zambia, and more than two-thirds of them indicated not to hate a single Chinese person.

Despite that there are complaints and discontent about Chinese people among the Zambian respondents, there is also substantial reason to believe that this discontent should not be interpreted as wholehearted anti-Chinese prejudice. Ashmore (1970) defines prejudice as "a negative attitude toward a socially defined group and any person perceived to be a member of that group" (p. 253). Pettigrew defines prejudice against a group as "antipathy accompanied by a faulty generalization" (Pettigrew 1980: 821, quoted in Quillian 1995: 587). If we strictly apply these two somewhat authoritative definitions, then negative attitudes, antipathy, and faulty generalizations of Chinese people were certainly found among the Zambian respondents. As Table 3 shows, 12.3 percent of the respondents said to hate "a few" Chinese people. However, it is not a blind, inflexible negative attitude that governs the views of most Zambians in this survey. First, in two other questions on the survey, when asked about the impact on Zambia of the Chinese presence, 14 percent tends toward a negative impact, and 53 percent tends toward a positive impact (for 33 percent it is as much positive as negative). When asked about the impact on the individual respondent and his family and friends, 15 percent tended towards a negative evaluation, and 47 percent towards positive evaluation (for 37.5 percent the impact is as much positive as negative; one answer was missing for this question). Second, in two additional questions, 78.6 percent of the respondents reported that Zambia would "not at all" or "not really" be better off if all Chinese people would leave the country. And 65 percent of the respondents said that it would be "not at all" or "not really" be good for himself or his

73 (c) Centre for Chinese Studies, Stellenbosch University All Rights Reserved. 
Gérard van Bracht

family and friends if all Chinese people would leave Zambia. Third, the most pressing issues for the Zambian respondents are concentrated in a few areas: the treatment of Zambian workers and the moral behavior of Chinese people, especially the defilement case in Luanshya. These are two areas that are most critical for the respondents and that Chinese people and companies in Zambia are able to improve on. Fourth, the "indirect effects" as described above indicate that there is "hidden" appreciation of the contribution of Chinese people to Zambia, which is understated in the literature. Fifth, many staunch critics of the Chinese can still see some positive things about their presence. A woman in Chambishi who lost a cousin and friends in the 2005 BGRIMM explosion said that the Chinese "don't respect our culture, they've brought in counterfeit goods, but at the same time they've created jobs, even for those who are illiterate and reduced crime in the community because lots of people are working now." Conversely, Zambians who are very favorable about the Chinese presence will still point out areas that need improvement. A Zambian woman who has lived in China for fourteen years and now works for a Chinese company in Lusaka commented that Chinese companies that "treat the workers bad destroy the Chinese good name and the confidence the Zambians have in the [Chinese-Zambian] partnership." " The general picture that emerges from this analysis is similar to Sautman and Yan's (2009) conclusion that African's views of Chinese people are varied and not as negative as the Western media portray, nor as positive as the Chinese discourse makes them out to be. 


\section{AFRICAN \\ EAST-ASIAN \\ AFFAIRS \\ THE CHINA MONITOR}

\section{Analyzing Zambian views of Chinese people in Zambia}

The foregoing has argued that Zambian's perceptions contain negative elements. How can we explain the existence of these complaints? Six factors are particularly applicable to the case of Zambia: a feeling of threat, the role of politicians, high expectations, cultural factors, structural factors, and the role of the media.

First, part of Zambian people's complaints are rooted in real or perceived disputes over goals or resources, and feelings of threat resulting from this competition. Disputes and threat are often seen as a cause for prejudice and ethnic conflict (Esses et al.; 1998, Chua; 2003, McLaren; 2003, Esman; 2004, Stephan et al.; 2005). These disputes can be the result of economic competition for scarce resources or economic power (LeVine \& Campbell; 1972, Bobo; 1983); symbolic or cultural attacks on the beliefs, values and culture of the own group (Kinder \& Sears 1981; Sears 1988); or competition over political power.

For Zambians who work for Chinese companies, particularly in mining and construction, unsatisfactory work conditions are a major factor causing them to hold negative views of Chinese people, like this miner in Chambishi working for a Chinese mine: "Sometimes it hurts, you work for 30 days, somebody pays you $700.000 \mathrm{KW}$ [140 USD]. . . That is the root of all problems, it's the pay." Many miners say the work is hard and the pay too low, as another miner, on a permanent contract with a Chinese mine in Chambishi said: "I'm working very hard, and Chinese people earn good money, but I earn a little. . . There is nothing good [the Chinese are doing], because I'm suffering."10 According to him, Chinese people are "very much" a threat to Zambia, because "they have 
Gérard van Bracht

A survey of Zambian views on Chinese People and their

involvement in Zambia

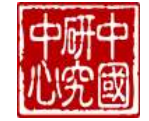

corrupted the government and don't look after the workers." In these statements, coming from low-paid miners, material conditions play a central role.

As for shops and restaurants, some evidence indicates the existence of conflict and a sense of threat. A self-employed business woman selling clothes and electronics in Chambishi commented that the Chinese "very much" pose a threat to her business: "It affects even my family, people don't buy from me but from the Chinese, it makes my family suffer." 11 This closely resembles Bonacich's (1973) thesis that ethnic migrants' economic activities often lead to conflicts with the host society, especially with local competitors and customers, who feel threatened in their livelihoods. However, conflicts do not always (solely) arise over material conditions. For various Zambian interviewees corruption was a major concern. A grocery store owner in Mufulira said that "the Chinese are corrupt, that's my major threat. The Chinese corrupt Zambian politicians." ${ }^{\prime 12}$ And a Zambian man, acting as a manager in a Chinese shop, complained about a sense of fear which he experiences while working for Chinese people: "Chinese don't care about our lives, they only want to get the money, that's all. . . . They don't follow the laws of Zambia. ... As an employee you can't do anything. The Chinese will say 'no this employee stole money' and bribe the Labour Minister, so they won't help the employee. . . . We Zambians that work for the Chinese, we just fear them, because they are the boss, they have got money." 13 Perception of cultural threat was also evident. One Zambian man who used to work for a Chinese mining firm in Chambishi said that "the Chinese don't like Zambian people going to church. The Chinese 


\section{AFRICAN \\ EAST-ASIAN \\ AFFAIRS \\ THE CHINA MONITOR}

say: 'Go to church and see if Jesus gives you money. You come work, I will give you money.' It's offensive, because they are serious about it."14

There is sufficient factual evidence to support the above views. Although the situation has improved over the last years, the Chinese-owned mine in Chambishi used to be the lowest paying mining firm among all mining firms in Zambia (Fraser \& Lungu; 2006). Labor unions in Zambia criticize Chinese construction firms for their tendency to maximize temporary labor. ${ }^{15}$ A Zambian employee of a Chinese shop in Livingstone reported earning 500.000 KW (100 USD) per month. ${ }^{16}$ A waiter in a Chinese restaurant in Lusaka said he earns $419.000 \mathrm{KW}$ (84 USD) per month, excluding tips, but "the boss keeps most of the tips." 17 Even though the minimum wage in Zambia was 584.000 KW (117 USD) per month at the time of research, these wages are not enough to sustain a family. Additionally, the Zambian government has a "very big challenge" with Chinese shop owners in Lusaka, because they, in violation of the Zambian labor law, often do not keep a proper record of paid wages and hours worked. ${ }^{18}$ With regard to corruption, Chinese companies are said to engage in bribery most often among all construction companies in Zambia, both Zambian and foreign. ${ }^{19}$

But the situation is not as straightforward as it seems. For instance, in the mining sector, Human Rights Watch (2011) concludes that, although abuses at other foreign mining firms also occur in Zambia, Chinese companies generally have the worst performance in terms of work conditions. However, currently, Chinese wages for skilled labor are comparable to other mines in Zambia, and the Chinese owned Luanshya mine even pays better than the Swiss/Canadian owned Mopani mine. ${ }^{20}$

77 (c) Centre for Chinese Studies, Stellenbosch University All Rights Reserved. 
Gérard van Bracht

A survey of Zambian views on Chinese People and their involvement in Zambia

Furthermore, all mining firms in Zambia, both Chinese and non-Chinese, hire contractors to do general construction work or temporarily fill in extra labor requirements, who pay less than the parent company (Sautman \& Yan; 2011). But because the Chinese are the major contractors in Zambia, the perception that Chinese contractors don't pay well is correct, because "the Chinese are the major contractors. But there are these non-Chinese contractors who equally pay badly." 21 Some Zambian and non-Chinese foreign investors pay their Zambian employees below minimum wage. ${ }^{22}$ And although some Chinese mining firms have evaded taxes through transfer pricing to the detriment of the Zambian government (Haglund; 2008), non-Chinese foreign mining companies in Zambia have also, through elaborate schemes, cheated the Zambian government in taxes from copper revenue (Sharife; 2011). In spite of this, Chinese people still bear the brunt of the criticism.

It must also be remarked that especially low-skilled and low-paid workers were prone to express fierce and negative attitudes towards "the Chinese" and to report higher levels of threat from the Chinese presence. Low-skilled workers are frequently concerned about the lack of respect which their Chinese managers accorded to them. A Zambian roller operator (with a monthly salary of between 500.000 and $750.000 \mathrm{KW}$, or between 100 and 150 USD) working for a Chinese construction company in Livingstone asserted that "nobody can say the Chinese do good things. They're not good investors. They insult us sometimes in Chinese... They can fire you, they don't care." ${ }^{23}$ Let us contrast this with a statement from a Zambian engineer (with a monthly salary of between 4 and 5 million KW, or between 800 and 1000 USD) working at the same Chinese construction company: "Workers enter a contract. Some- 


\section{AFRICAN \\ EAST-ASIAN \\ AFFAIRS \\ THE CHINA MONITOR}

body who has never been to school gets $500.000 \mathrm{KW}$ [100 USD], can't speak proper English, how do you expect them to earn a high salary? Less educated Zambians have too high expectations. If [this Chinese company] was not here, most of these people would not have a job... The crime rate would escalate." ${ }^{24}$ When asked if Chinese people in any way pose a threat to his interests, a welder (with a relatively high monthly salary of between 2 million and 2.5 million KW, or between 400 and 500 USD) working for a Chinese mine in Chambishi replied "Not at all. In the future a Chinese person might take my job but the chance is not high. They can take my job but not my knowledge." 25

The feeling of being threatened and conflicts over real issues, such as about wages, are viable explanations for negative sentiments among Zambian people. However, high-skilled Zambians and those who do not feel directly economically, culturally or politically threatened also expressed complaints about the effect of the behavior of Chinese people on Zambia, without being affected themselves by Chinese behavior. A medical doctor in Mufulira, for instance, who thinks Chinese people do not pose a threat to his own interests at all, but do threaten the interests of Zambians in general, sees several forms of negative impact of their presence on Zambia, for example the fact that they don't integrate well into Zambian society and that Chinese employers do not transfer skills and knowledge to their Zambian employees. ${ }^{26}$ Genuine conflicts of interest do happen at the personal level and personal grievances transmitted through conversations - influence the opinions of others. At the same time, the individual's environment, through interactions with other people, rumor and gossip, the reports they hear in the media, and statements from politicians also influence the views and threat

79 (c) Centre for Chinese Studies, Stellenbosch University

All Rights Reserved. 
Gérard van Bracht

A survey of Zambian views on Chinese People and their involvement in Zambia

perceptions of an individual (Rothbart and John 1985), creating a public discourse on Chinese people in Zambia. Rosenstein (2008) has found this effect for racial relations in the USA: "One situation where a group threat can spawn a personal threat is if a person believes that her neighborhood will deteriorate with the influx of blacks and she extrapolates that her own house will consequently lose value" (p. 1131). As complaints of disgruntled Zambians - some with a real base, some without one - about the Chinese are transmitted throughout the Zambian nation, perceptions can become reality, and Zambians who are not directly affected by Chinese activities may become more sensitive to a real or perceived threat, simply because other Zambians are affected.

Some authors argue that Michael Sata has played a crucial role in creating or exacerbating perceptions of Chinese threat among Zambians. Sautman and Yan (2009) point out that Botswana and Zambia have anti-Chinese sentiment, because it was turned into an issue by local politicians. Patel (2006) argues that Michael Sata has, albeit to a lesser degree, also used Indian and Lebanese foreign investors as a scapegoat to win votes. How valid is this idea? As in 2006, during the 2011 election campaign Mr. Sata singled out Chinese investors and criticized them for not creating quality jobs, that their investment does not benefit Zambian society enough, and that some Chinese traders are not genuine investors and compete unfairly with small Zambian businesses. ${ }^{27}$ This criticism helped him to win votes in the key Zambian constituencies of Lusaka and the Copperbelt Province (Masterson; 2011). Interestingly, Mr. Sata hosted a lunch for the Chinese business community in Zambia immediately after being elected (The Guardian; 3 November 2011). And since September 2011, Mr. Sata has toned down his anti-Chinese 


\section{AFRICAN \\ EAST-ASIAN \\ AFFAIRS \\ THE CHINA MONITOR}

rhetoric (Mail \& Guardian; 14 June 2012). Can Mr. Sata's turn-about on Chinese people explained by political opportunism? It would be wrong to dismiss Mr. Sata as a populist merely satisfying his own political ambitions. Mr. Sata could only get elected, because he raised certain real problems, conflicts over real interests that genuinely concern the Zambian people - corruption, mistreatment of Zambian laborers, the wealth gap - that were neglected by the MMD government (Larmer \& Fraser ; 2007, The New York Times; 31 October 2011b). However, as this paper shows, at the same time there is a level of unfairness in his rhetoric, because some accusations of Chinese people in Zambia have been exaggerated or not put into a proper context. For example, as was shown above, although some Chinese engage in illegal activities in Zambia, other foreign and Zambian firms do so as well. Why put the spotlight mainly on Chinese investors?

Perhaps some Zambians are disappointed in the boon that the Chinese were expected to bring to Zambia. Throughout the interviews, some Zambians were found having high expectations of the role that China should play in Zambia. For example, on a Saturday morning the author was chatting with a Zambian market salesman at a busy market in Lusaka. Heavy rains of the previous night had turned the sand roads of the market into a foot-deep stream of mud. When asked whether the Chinese presence has any negative impact on his life, the market sales man looked at the road and said that he would like the Chinese to "maintain our roads, especially here in Soweto we need drainage," making it sound as if Chinese people have a responsibility to take care of this. ${ }^{28}$ Similarly, a woman in Chambishi commented that "the Chinese don't assist the poor people in Zambia. We just want help, assistance to

81 (c) Centre for Chinese Studies, Stellenbosch University

All Rights Reserved. 
Gérard van Bracht

A survey of Zambian views on Chinese People and their involvement in Zambia

my children. They don't visit people, see how the people live and how they are doing, doing something for the people." 29

This outlook, when transplanted to a work environment, can also be a source of conflicts between employer and employee. Chinese people in Zambia invariably contrast their own work style which emphasizes diligence (qinfen 勤奋) with the work ethic of their Zambian employees, who in their eyes are idle (landuo 懒惰). ${ }^{30}$ One can argue that these views are heavily informed by ethnocentrism and racial stereotypes. However, some Zambians, like this Zambian engineer working for a private Chinese construction company, shares Chinese peoples' view: "On Monday most Zambian general workers don't report for work early, sometimes they'd even miss out, because they drank too much, they did too much of everything... The moment they get money, they'd just knock off early from work or buy sachets of liquor and start drinking on the work site... That's how undisciplined they are. It's dangerous at the site. When the Chinese say something about it the Zambian workers think the Chinese are harsh... But the fact is they were drinking on site."31 These irresponsible acts by Zambian workers anger their Chinese colleagues, who, as Lee (2009) explains, "demand of their African workers the same work ethics and sacrifice they believed have allowed the Chinese to develop, and which have yet to be found among the African workforce" (p. 654). Zambian workers, on the other hand, feel a sense of exploitation, because current wages and benefits are much less generous than during the high tide in the 1970s when the Zambian government ran the mines (Lee; 2009, Fraser \& Lungu; 2006). 


\section{AFRICAN \\ EAST-ASIAN \\ AFFAIRS \\ THE CHINA MONITOR}

This cultural clash goes the other way as well. Chinese people living in Africa tend to isolate themselves from the local communities (Park 2009). According to Lee (2009), this is the case in Chambishi, where Chinese workers live in secluded areas, usually speak very little English or local languages, and rarely interact with Zambians in their spare time. This is also how most Chinese people who were interviewed for this research live. As a Chinese engineer points out, after three months in Zambia, besides during his work he has had contact with few Zambians. ${ }^{32}$ And a Chinese man working for a Chinese construction company said that "normally we don't got outside. Maybe because of security reasons. There have been quite a lot of incidents directed against Chinese people." 33 According to intergroup contact theory, contact between people from different ethnic groups will lead to less mutual prejudice and more positive views of each other (Allport; 1954, Pettigrew \& Tropp; 2006). However, besides the existence of contact, the type and meaningfulness of this contact are also important (Amir; 1969; Pettigrew; 1998). Although these figures are not generalize to Zambia, of the 155 respondents, $26 \%$ work or have worked for or with Chinese people, $8.5 \%$ have Chinese neighbors, $10 \%$ have Chinese acquaintances, $18 \%$ have visited Chinese doctors or clinics, and $82 \%$ stated having visited a Chinese shop. But it is unclear how meaningful the contact of each of these types of interaction are in reality. The sample also contained 39 Zambians who indicated having Chinese friends, one of the most meaningful forms of interethnic contact (Cook; 1962, Pettigrew; 1998). However, the interpretation of friendship can be very broad. And having Chinese friends does not necessarily translate into positive views of Chinese people, as a woman in Chambishi who conducts business with Chinese 
Gérard van Bracht

A survey of Zambian views on Chinese People and their involvement in Zambia

people, has Chinese friends in Botswana and visits Chinese clinics, observes: "Chinese people are very harsh, they don't understand Zambian people." ${ }^{34}$ Language is arguably a key barrier in the interaction between Zambians and Chinese, causing friction, as an electrician at a large Chinese mining company said about his Chinese supervisors: "Wherever I'm standing, they will be standing next to me, they will be busy shouting insults at you in their own language. A Zambian interpreter told me, when [a Chinese person] says this, he is actually insulting your mother." ${ }^{, 35}$ In practice, as a Zambian engineer working for a large Chinese private construction company explains, this easily leads to misunderstandings between Chinese employers and Zambian employees, "because if you don't understand each other you end up arguing. One guy is saying this, you are saying that, but at the end of the day you are saying the same, but not communicating rightly.",36

Zambian anti-Chinese sentiment also originates from situations created by policies and acts of previous Zambian governments, which willingly or unwillingly have allowed abuses to take place. Although Zambia has been independent for more than fifty years and enjoyed an average GDP economic growth of 5.6 percent from 2001 to 2010, the country, with an average per capita GDP of around 1000 USD, remains one of the poorest on earth (The World Bank 2011). Corruption has been endemic in Zambia for decades (Ihonvbere; 1996), and it still is. ${ }^{37}$ These structural factors lower the bargaining position of the Zambian government vis-àvis foreign investors, for instance to counter abuses or raise minimum wages. A concomitant factor is that some Zambian government institutions lack capacity to deal with abuses by foreign investors in the mines (Human Rights Watch; 2011). Haglund (2008) asserts that 


\section{AFRICAN \\ EAST-ASIAN \\ AFFAIRS \\ THE CHINA MONITOR}

Chinese companies trying to cut corners in the Zambian mining industry is the result of a combination of a weak compliance culture in China on the one hand and weak regulatory and political institutions, lack of transparency and capacity constraints in Zambia on the other hand. Taylor (2009) argues that Chinese compliance is generally higher in African countries with strong regulatory frameworks and enforcement capacity. The structural and institutional framework in which these Chinese companies operate may explain why abuses, which have shaped Zambian perceptions of Chinese people, were allowed to happen. Although Chinese companies obviously have a responsibility to prevent these problems from arising, the Zambian government also needs to enforce its own laws. Additionally, Kragelund (2009) argues that Western anxiety of Chinese expanding activities in Zambia is partially self-inflicted, because it were the Western countries who forced Zambia to adopt economic policies that enabled China to invest in Zambia. This gives credence to the idea that abuses and the consequent negative attitudes towards Chinese people are the result of a shared responsibility by Zambian, Chinese and non-Chinese foreign actors in Zambia.

Several Western and Chinese scholars blame the (Western) media for stirring up anti-Chinese sentiment among Africans (e.g., see Li Anshan 2008; Wang Xuejun 2009; Li Pengtao 2010; Sautman \& Yan 2008, 2009; Wainaina 2012). A vice editor of a Zambian daily newspaper argues that Western reporting about Chinese activities in Zambia is "not balanced and fair," "biased and mainly one sided" and sometimes "exaggerated", because the Western reporting mainly emphasizes the negative side of Chinese investments. ${ }^{38}$ Another Zambian journalist argues that "it is very possible" that the media in Zambia play a role in 
Gérard van Bracht

A survey of Zambian views on Chinese People and their involvement in Zambia

distorting views of the Chinese, because it is "pretty common" that Zambian journalists "emotionally attach themselves to the cause of the [Zambian] people". 39 For the respondents in the survey sample, newspapers and television ranked second (27.2\%) as their most important source of information on Chinese people and their activities in Zambia, behind personal experience or personal observation (46\%), but before "what other Zambians say about Chinese people" (20.4\%), and government policy/government information (4.9\%). ${ }^{40}$ However, as another Zambian journalist points out, the media can also expose real abuses to the benefit of Zambian people. "The media" is also a rather nebulous concept. Its precise impact on Zambian people's perceptions and its relative importance vis-à-vis other factors that shape Zambian people's perceptions is hard to quantify. But at the very least, this paper has shown that the perception that Zambians generally dislike Chinese people is too sweeping. There is more appreciation of the contribution of Chinese people and companies to Zambia than written publications on "China in Zambia" make them out to be. This problem also speaks to the wider China-in-Africa discourse as reflected in popular books, like Halper's (2010), who argues that "Beijing pours billions of dollars in gifts and low-interest loans into the coffers of corrupt African regimes," which "provide access to resources and a dumping ground for poor-quality products" (p. 99). In another book one reads that "all Beijing's posturing, its talk of 'ethics' and the rest, seems merely cosmetic, a way of presenting itself as a responsible, benevolent ally of the suppressed that refuses to get involved in conflicts so as to arbitrate disinterestedly and secure the pax Sinica" (Michel, Beuret \& Woods 2009: 144). The problem is not that these portrayals are necessarily 


\section{AFRICAN \\ EAST-ASIAN \\ AFFAIRS \\ THE CHINA MONITOR}

(entirely) wrong. The problem is that these one-sided accounts paint a black and white picture of Chinese people and their activities in Africa that does not do sufficient justice to the far more nuanced and complex truth.

\section{Conclusion}

Rather than altogether dispelling the notion that there is widespread anti-Chinese resentment in Zambia, this paper has provided evidence that nuances this perception. Zambian people's perceptions of Chinese people in Zambia are not as unfavorable as some media and (popular) books on China present. Zambians have numerous complaints, many of which are justified, but there are also mitigating factors which are understated in the mainstream view of China's engagements with Africa. The views of most Zambians of Chinese people contain both positive and negative elements, including indirect effects which are not highlighted in the literature or media reports on Zambia. Just as Chatelard (2011) argues that China's interactions with Africa should be seen as a multifaceted process involving different actors, Zambian people's views of Chinese people in Zambia are likewise multifaceted, and more complex than can be captured in a magazine article.

This article has also shown some of the interplay between the factors which are responsible for, on one hand, this partial misperception that there is widespread anti-Chinese resentment in Zambia; and on the other hand, the accurate perception that many Zambians have complaints about the Chinese activities in their country. Real conflicts over values and material interests mix together with misperceptions and cultural differences to create perceptions of Chinese people that have become

87 (c) Centre for Chinese Studies, Stellenbosch University

All Rights Reserved. 
embedded in the Zambian mind. The Zambian public discourse on Chinese people, which is both the origin and the result of this blend, does contain many "grains of truth", but has also gone to live a life on its own, and influence the attitudes and behavior that the Zambian majority displays against the Chinese minority in Zambia. As complaints of disgruntled Zambians about the Chinese are transmitted throughout the Zambian nation, Zambians who are not directly affected by the Chinese, may also become predisposed against Chinese people. Politicians, eager to stand up for the people and to win the popular vote, have turned the Chinese presence in Zambia into a political issue. The media pick up this sentiment, and sometimes filter out the nuances and inflate these stories. Although none of the above factors is quantifiable, nor is their relative weight to each other clear, this paper has presented reasonable evidence that each one of them plays a significant role in the process that has shaped Zambians' perceptions of Chinese people, and outsiders' perceptions of this situation. Culpability for conflicts between the two nationalities is diffused among different actors, and it is the responsibility and in the interest of all to prevent these misperceptions from exacerbating, and to work together to improve their ethnic relations.

\section{End Notes}

${ }^{1}$ Interview with Chinese senior spokesperson of large state-owned Chinese construction company, Lusaka, 19 January 2012.

${ }^{2}$ Interview with two experts from the Road Development Agency, Lusaka, 18 January 2012; Interview with expert from the National Road Fund Agency, Lusaka, 24 January 2012.

${ }^{3}$ Interview with Zambian mechanical engineer, Chambishi, 5 February 2012. 


\section{AFRICAN \\ EAST-ASIAN \\ AFFAIRS}

THE CHINA MONITOR

Issue 1

August 2012

${ }^{4}$ Interview with social economic planner at municipal government, Chambishi, 1 February 2012.

${ }^{5}$ Interview with owner of grocery store, Chambishi, 4 February 2012.

${ }^{6}$ Interview with Zambian journalist, Lusaka, 27 December 2011.

${ }^{7}$ Interview with Zambian saleslady in clothes boutique, Chambishi, 1 February 2012 .

${ }^{8}$ Interview with Zambian woman who works for a Chinese company, Lusaka, 16 January 2012.

${ }^{9}$ Interview with Zambian electrician at Chinese mining company, Chambishi, 31 January 2012.

${ }^{10}$ Interview with Zambian miner (gun attendant) at Chinese mining company, Chambishi, 5 February 2012.

11 Interview with Zambian owner of shop selling clothes and electronics, Chambishi, 31 January 2012.

${ }^{12}$ Interview with Zambian grocery store owner, Mufulira, 12 February 2012. Some other interviewees who mentioned corruption by Chinese people as a problem: Interview with head teacher at a primary school, Mufulira, 5 February 2012; Interview with Zambian saleslady at market, Chambishi, 31 January 2012; Interview with Zambian bank employee, Livingstone, 12 December 2011.

${ }^{13}$ Interview with Zambian manager of a Chinese shop, Lusaka, 28 January 2012.

${ }^{14}$ Interview with unemployed Zambian man, previously working for a Chinese mining company, Chambishi, 31 January 2012.

${ }^{15}$ Interview with Labour Union representative, Livingstone, 14 December 2011.

${ }^{16}$ Interview with Zambian asset protector in a Chinese shop, Livingstone, 19 December 2011.

${ }^{17}$ Interview with Zambian waiter at a Chinese restaurant, Lusaka, 17 January 2012.

${ }^{18}$ Interview with Senior Labour Officer, Ministry of Labour and Social Security, Lusaka, 26 January 2012. 
Gérard van Bracht

A survey of Zambian views on Chinese People and their

involvement in Zambia

19 Interview with expert, National Council for Construction, Lusaka, 16 January 2012.

${ }^{20}$ Interview with Zambian mechanical engineer, Chambishi, 5 February 2012.

${ }^{21}$ Interview with Zambian mechanical engineer, Chambishi, 5 February 2012.

22 Interview with Senior Labour Officer, Ministry of Labour and Social Security, Lusaka, 26 January 2012. Additionally, a small-scale survey in Kamwala market in Lusaka by this author found that a number of Zambian shop-owners pay less than minimum wage to their Zambian employees. Managers of South African owned supermarkets Pick N Pay (Lusaka) and Shoprite (Mufulira) refused to provide information to this author about work conditions of their Zambian employees.

23 Interview with Zambian roll driver and operator working for a Chinese construction company, Livingstone, 16 December 2011.

24 Interview with Zambian engineer working for a Chinese construction company, Livingstone, 7 December 2011.

25 Interview with Zambian technician working for a large Chinese mining firm, Chambishi, 1 February 2012.

${ }^{26}$ Interview with Zambian medical doctor, Mufulira, 12 February 2012.

${ }^{27}$ Interview with President Sata’s Deputy Press Secretary, 10 January 2012.

${ }^{28}$ Interview with Zambian market salesman of shoes, Lusaka, 28 January 2012.

29 Interview with Zambian market sales woman selling sweet potato leaves, Chambishi, 3 February 2012.

30 Interview with Chinese senior spokesperson of large state-owned Chinese construction company, Lusaka, 19 January 2012; Interview with Chinese engineer of large private Chinese construction company, Lusaka, 21 January 2012; Interview with Chinese restaurant owner, Lusaka, 13 January 2012; Interview with Chinese director of private Chinese construction company, Livingstone, 10 December 2011.

31 Interview with a Zambian engineer working for a large private Chinese construction company, Lusaka, 25 January 2012. 


\section{AFRICAN \\ EAST-ASIAN \\ AFFAIRS}

THE CHINA MONITOR

Issue 1

August 2012

${ }^{32}$ Interview with Chinese engineer working at telecom company, Livingstone, 27 November 2011.

33 Interview with Chinese senior spokesperson of large state-owned Chinese construction company, Lusaka, 19 January 2012.

34 Interview with Zambian owner of shop selling clothes and electronics, Chambishi, 31 January 2012.

${ }^{35}$ Interview with Chinese electrician at large Chinese mining company, 31 January 3012 .

36 Interview with a Zambian engineer working for a large private Chinese construction company, Lusaka, 25 January 2012.

${ }^{37}$ Currently Zambia ranks place 91 out of 182 on Transparency International's corruption perceptions index (2011). http://archive.transparency.org/content/ download/64426/1030807 (Accessed: 8 July 2012).

${ }^{38}$ Interview with Zambian journalist working for national newspaper, Lusaka, 6 January 2012.

${ }^{39}$ Interview with Zambian journalist working for national newspaper, Lusaka, 3 January 2012.

${ }^{40}$ Three respondents did not answer this question or answered "I don't know".

${ }^{41}$ Interview with managing director of national Zambian newspaper, Lusaka, 9 January 2012.

\section{References}

Allport, G. W. 1954. The Nature of Prejudice. Cambridge, Mass.: Addison-Wesley.

Amir, Y. 1969. "Contact hypothesis in ethnic relations." Psychological Bulletin vol. 71, no. 5, pp. 319-342.

Ashmore, Richard D. 1970. "Prejudice: Causes and Cures." in Collins, B. E. \& Ashmore, R. A. (eds.). Social Psychology: Social Influence, Attitude

91 (c) Centre for Chinese Studies, Stellenbosch University All Rights Reserved. 
Gérard van Bracht A survey of Zambian views on Chinese People and their involvement in Zambia

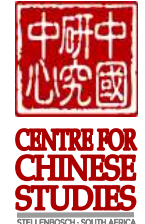

Change, Group Processes, and Prejudice. Reading, MA: Addison-Wesley, pp. 245339.

Bank of Zambia. 2011. Zambia Direction of Trade Report, First Quarter 2011. Lusaka.

BBC News. 2011. "Chinese chicken farmers ruffle Zambian feathers." 5 February .

Blumer, H. 1958. "Race prejudice as a sense of group position." The Pacific Sociological Review vol. 1, no. 1, pp. 3-7.

Bobo, L. 1983. "Whites' Opposition to Busing: Symbolic Racism or Realistic Group Conflict?." Journal of Personality and Social Psychology vol. 45, no. 6, pp. 1196-1210.

Bobo, L. \& Vincent L. Hutchings. 1996. "Perceptions of Racial Group Competition: Extending Blumer's Theory of Group Position to a Multiracial Social Context." American Sociological Review vol. 61 (December), pp. 951-972.

Bonacich, E. 1972. "A Theory of Ethnic Antagonism: The Split Labor Market." American Sociological Review vol. 37, no. 5, pp. 547-559.

Bonacich, E. 1973. "A Theory of Middleman Minorities." American Sociological Review vol. 38, no. 5, pp. 583-594.

Brautigam, D. 2009. The Dragon's Gift: The Real Story of China in Africa. Oxford: Oxford University Press.

Chatelard, S. 2011. "Unpacking the new 'scramble for Africa'. A local and critical perspective of Chinese activities in Zambia," in Seidelmann, R., Marques, J. L. \& Vasilache, A (eds.). States, Regions, and the Global System: Northern Asia Pacific, Europe and Today's Globalisation. Baden Baden: Nomos, pp. 175-197.

Chua, A. 2003. World on Fire: How Exporting Free Market Democracy Breeds Ethnic Hatred and Global Instability. New York: Doubleday.

Cook, S. W. 1962. "The Systematic Analysis of Socially Significant Events: A Strategy for Social Research.” Journal of Social Issues vol. 18, no. 2, pp. 66-84. 


\section{AFRICAN \\ EAST-ASIAN \\ AFFAIRS}

THE CHINA MONTTOR

Issue 1

August 2012

Dobler, G. 2009. "Chinese Shops and the Formation of a Chinese Expatriate Community in Namibia." The China Quarterly vol. 199 (September), pp. 707727.

The Economist. 2011. "Trying to pull together: Africans are asking whether China is making their lunch or eating it." 20 April.

Esman, M. J. 2004. An Introduction to Ethnic Conflict. Oxford, UK: Polity.

Esses, V. M., Jackson, L. M. \& Armstrong, T. L. 1998. “Intergroup Competition and Attitudes Toward Immigrants and Immigration: An Instrumental Model of Group Conflict.” Journal of Social Issues vol. 54, no. 4, pp. 699-724.

Fraser, A \& Lungu, J. 2006. For whom the windfalls? Winners \& losers in the privatization of Zambia's copper mines. Lusaka: CSTNZ.

Gadzala, A \& Hanusch, M. 2010. "African perceptions on China-Africa: Gauging popular perceptions and their economic and political determinants." Afrobarometer Working Papers Working Paper no. 117, January.

The Guardian. 2011. "Zambian president urged to protect workers at Chinese-owned mines." 3 November.

Haglund, D. 2008. "Regulating FDI in weak African states: a case study of Chinese copper mining in Zambia." The Journal of Modern African Studies vol. 46, pp. 547-575.

Halper, S. A. 2010. The Beijing consensus: How China's authoritarian model will dominate the twenty-first century. New York: Basic Books.

Haugen, H \& Carling, J. 2005. "On the edge of the Chinese diaspora: The surge of baihuo business in an African city." Ethnic and Racial Studies vol. 28, no. 4 (July), pp. 639-662.

Human Rights Watch. 2011. 'You'll be fired if you refuse': Labor Abuses in Zambia's Chinese State-owned Copper Mines. HRW Report, November, pp. 1-122.

93 (c) Centre for Chinese Studies, Stellenbosch University All Rights Reserved. 
Gérard van Bracht A survey of Zambian views on Chinese People and their involvement in Zambia

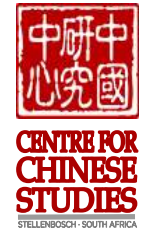

Huynh, Tu T., Park, Y. J. \& Chen, A. 2010. "Faces of China: New Chinese Migrants in South Africa, 1980s to Present." African and Asian Studies vol. 9, pp. 286-306.

Ihonvbere, J. O. 1996. Economic crisis, civil society, and democratization: The case of Zambia. Trenton and Asmara: Africa World Press.

Inter Press Service. 2012. "Chinese Underage Sex Scandal Sparks Emotive Debate.” January 31.

Kinder, D. R. \& Sears, D. O. 1981. "Prejudice and Politics: Symbolic Racism Versus Racial Threats to the Good Life." Journal of Personality and Social Psychology vol. 40, no. 3, pp. 414-431.

Kragelund, P. 2009. "Knocking on a wide-open door: Chinese investments in Africa." Review of African Political Economy vol. 36, issue 122, pp. 479-497.

Larmer, M. \& Fraser, A. 2007. "Of Cabbages and King Cobra: Populist Politics and Zambia's 2006 Elections.” African Affairs vol. 106, no. 425, pp. 611- 637.

Lee, C.K. 2009. "Raw Encounters: Chinese Managers, African Workers and the Politics of Casualization in Africa's Chinese Enclaves." The China Quarterly vol. 199 (September), pp. 647-666.

LeVine, R. A. \& Campbell, D. T. 1972. Ethnocentrism: Theories of Conflict, Ethnic Attitudes, and Group Behavior. New York: Wiley.

LI, A. 2008. "Wei Zhongguo zhengming: Zhongguo de Feizou zhanlve yu guojia xingxiang [Rectifying China's name: China's Africa strategy and its national image]." Shijie jingji yu zhengzhi no. 4, pp. 6-15.

LI, P. 2010. "Zhongfei guanxi de fazhan yu Feizhou Zhongguo xin yimin [The development of Sino-African relations and new Chinese migrants in Africa]." Huaqiao huaren lishi yanjiu no. 4 (December), pp. 24-30.

Lusaka Times. 2012. "Chinese Nationals accused of defiling under-age Zambian girls acquitted, Police Officers blamed." 6 March. 


\section{AFRICAN \\ EAST-ASIAN \\ AFFAIRS}

THE CHINA MONITOR

Issue 1

August 2012

Ma Mung, E. 2008. "Chinese Migration and China's Foreign Policy in Africa." Journal of Chinese Overseas vol. 4, no.1 (May), pp. 91-109.

Mail \& Guardian. 2012. "Zambians lose hope as 'King Cobra' lives up to his nickname." 14 June.

Marfaing, L. \& Thiel, A 2011. "Chinese Commodity Imports in Ghana and Senegal: Demystifying Chinese Business Strength in Urban West Africa." GIGA Working Paper no. 180.

Masterson, G. 2011. "What Sata's victory means for Zambia." South African Broadcasting Corporation Online. October 6.

McLaren, L. M. 2003. "Anti-Immigrant Prejudice in Europe: Contact, Threat Perception, and Preferences for the Exclusion of Migrants." Social Forces vol. 81, no. 3, pp. 909-936.

Michel, S., Beuret, M. \& Woods, P. 2009. China safari: On the trail of Beijing's expansion in Africa. New York: Nation Books.

Le Monde. 2011. "En Zambie, le soulagement après la victoire de 'King Cobra' à la présidentielle." 23 September.

New York Times. 2010. "Zambia Uneasily Balances Chinese Investment and Workers' Resentment.” 20 November.

The New York Times. 2011a. "Zambia Drops Case of Shooting by Chinese Mine Bosses." 4 April.

The New York Times. 2011b. "An exceptional change in Zambia, and via the ballot box, too." 31 October.

Park, Y. J. 2009. “Chinese migration in Africa.” SAIIA Occasional Paper, no. 24 (January).

Patel, N. 2006. "A Quest for Identity: the Asian Minority in Africa." Publications of the Institute of Federalism Fribourg Switzerland, Travaux de recherche, cahier

95 (c) Centre for Chinese Studies, Stellenbosch University All Rights Reserved. 
no. 38 .

Pettigrew, T. F. 1980. "Prejudice," in Themstrom, S., Orlov, A. \& Handlin, O. The Harvard Encyclopedia of American Ethnic Groups. Cambridge, MA: The Belknap Press.

Pettigrew, T. F. 1998. "Intergroup Contact Theory." Annual Review of Psychology vol. 49 , pp. 65-85.

Pettigrew, T. F. \& Tropp, L. R. 2006. "A Meta-Analytic Test of Intergroup Contact Theory." Journal of Personality and Social Psychology vol. 90, no. 5, pp. 751-783.

Quillian, L. 1995. "Prejudice as a response to perceived group threat: Population composition and anti-immigrant and racial prejudice in Europe." American Sociological Review vol. 60, no. 4 (August), pp. 586-611.

Rosenstein, J. E. 2008. "Individual threat, group threat, and racial policy: Exploring the relationship between threat and racial attitudes." Social Science Research vol. 37, pp. 1130-1146.

Rothbart, M. \& John, O. P. 1985. "Social Categorization and Behavioral Episodes: A Cognitive Analysis of the Effects of Intergroup Contact." Journal of Social Issues vol. 41, no. 3, pp. 81-104.

Sata, M. C. 2007. "Chinese Investment in Africa and Implications for International Relations, Consolidation of Democracy and Respect for Human Rights: The Case of Zambia." Paper presented to the Harvard University Committee on Human Rights Studies Events Series 24 October, pp. 1-12.

Sautman, B. \& YAN H. 2007. "Friends and interests: China's distinctive links with Africa." African Studies Review vol. 50, no. 3, pp. 75-114.

Sautman, B. \& YAN H. 2008. "The forest for the trees: Trade, investment and the China-in-Africa discourse.” Pacific Affairs vol. 81, no. 1 (Spring), pp. 9-29.

Sautman, B. \& YAN H. 2009. "African perspectives on China-Africa links.” The 


\section{AFRICAN \\ EAST-ASIAN \\ AFFAIRS}

THE CHINA MONITOR
Issue 1

August 2012

China Quarterly vol. 199 (September), pp. 729-759.

Sautman, B. \& YAN H. 2011. "Barking up the wrong tree: Human Rights Watch and Chinese copper mining in Zambia." Pambazuka News issue 563, 14 December.

Sears, D. O. 1988. "Symbolic Racism." in Katz, P. A. \& Taylor, D. A. (eds.). Eliminating Racism: Profiles in Controversy. New York: Plenum Press, pp. 53-84.

Sharife, K. 2011. “Transparency' hides Zambia's lost billions.” Aljazeera Online. June 18 .

Stephan, W. G., Ybarra, O., Martinez, C. M., Schwarzwald, J. \& Tur-Kaspa, M. 1998. "Prejudice toward immigrants to Spain and Israel: an integrated threat theory analysis." Journal of Cross-Cultural Psychology vol. 29, no. 4 (July), pp. 559-576.

Stephan, W. G., Lausanne Renfro, C., Esses, V. M., Stephan, C. W. \& Martin, T. 2005. "The effects of feeling threatened on attitudes toward immigrants." International Journal of Intercultural Relations vol. 29, no. 1, pp. 1-19.

Taylor, I. 2009. China's New Role in Africa. London: Lynne Rienner.

The Telegraph. 2006. "Rioters attack Chinese after Zambian poll." 3 October.

The World Bank. 2011. "Zambia: Country Brief," April. Available online: http:// go.worldbank.org/FEPSKV1TZ0 (Accessed on 7 July 2012).

WANG, X. 2009. "Feizhou feizhengfu zuzhi yu Zhongfei guanxi [African NGOs and Sino-African relations]." Xiya Feizhou no. 8, pp. 56-62.

Wainaina, B. 2012. "How not to write about Africa in 2012 - a beginner's guide." The Guardian. June 3. 